\title{
An Unlikely Pair: Disturbance and Intimacy in an Interracial 'Empire Family'
}

\section{JANE McCABE}

It was on a Monday morning, 23 April 1906, after several delays due to 'a terrible spell of weather' that Egerton Peters set his two young children, Lorna aged four and George aged two, on a one-way journey away from their tea plantation home in Assam. The children were accompanied by their father for the first leg of the journey by boat from remote Cachar to the nearest town, where they were put in the hands of a 'reliable man' to make the two-day rail journey to Ghoom, in the Darjeeling district of Bengal, northeast India. At Ghoom they were to be met by a representative of the St Andrew's Colonial Homes, who would escort them to their destination, the tiny hill station of Kalimpong. At 1.22pm the following day, Peters dispatched a telegram to the Homes advising of the children's departure and 'trusting arrangements for meeting them alright'.

This moment of separation from their father represented both a beginning and an end for the children. They would never see their mother again, nor their extended kin on the tea plantation, nor Assam itself. And it would be 20 years before they would again meet their father, not in India but in far off New Zealand. As for beginnings, this was the moment from which the trajectories of their lives were defined by their categorization as Eurasian, a term that was widely understood as indicating an ancestry that included a male European, but was otherwise ambiguous. ${ }^{2}$ Classification as Eurasian was essentially a negative distinction, a classification of what one was not (i.e. not European, not Asian). What it meant one was was often unclear. At the Homes in Kalimpong, Lorna and George would learn of this negative distinction by being housed with other Eurasians and raised in a European environment. As young adults they would be relocated to New Zealand as part of the Homes' systematic scheme to provide an alternative future to the discrimination Eurasians faced in British India. This connection - of a racialized upbringing in India to a colonial solution in New Zealand - presents a poignant opportunity to understand the crucial role of place in limiting or enabling contact in an interracial family.

This essay explores the relationship between Lorna Peters and her father. The shifting dynamics of their relationship in the various spaces they occupied vividly contrasts the weight of social pressure in British India with the relative absence of such in New Zealand. Four distinct phases can be identified, and these form the sections of this essay. The first occurred within the bounded but relatively free space of a tea plantation, where Lorna spent her first four years cared for mostly by her Nepali mother but (at least in Egerton's words) forming an affectionate bond with her father. This was followed by 15 years institutionalized at the Homes, which began with Lorna's sudden separation from her parents in 1906 and was characterized by her attempts to communicate with her father from 1912 onwards. Direct contact of any kind with his daughter was avoided by Peters until the third phase of the relationship, when Lorna left India for New Zealand in 1920. This spatial change in circumstance prompted a profound and immediate shift in the boundaries of their relationship, with Peters for the first time writing to his daughter directly. This communication continued until Peters himself travelled to New Zealand in 1926. There he not only directly associated but resided with his daughter, formed a partnership in business with her, and was to share a home with her and her new family for the rest of his life. 
I argue that a fourth subtle but distinct phase in their relationship emerged about the time of Lorna's marriage, as she seemed to gain an upper hand in not only her relationship with her father but also with her life.

Rather than focus on the political or legislative framework that governed or made inevitable these intense moments in a family history, my approach here is to explore the affective domain that surrounded and informed them. This approach illuminates the management of Lorna's relationships by the Homes in Kalimpong - a vibrant example of the 'severing and suturing' of affective ties - and in addition offers a view of the longer term consequences of such intrusions. ${ }^{3}$ Looking at the Peters family over a period of almost 50 years, it can be fruitfully understood as a disrupted branch of an established colonial family, the likes of which have often been excluded from historical scholarship. As Tony Ballantyne has recently pointed out, Elizabeth Buettner's comprehensive 'Empire Families' unapologetically focuses on the 'middle rank of colonial families', with an absence of Eurasian or South Asian perspectives. ${ }^{4}$ Archives can be problematic in addressing this imbalance, but the issue here is more to do with what counts as an archive, and (perhaps even more importantly) the impact of the shame and silence associated with interracial families during the latter part of empire. Bringing family histories into the academic realm has the capacity to productively disrupt accepted narratives, as Tanya Evans has observed. ${ }^{5}$ Family secrets and buried pasts can impact the way in which history at a broader level is written and understood. This is particularly relevant to colonial histories, given that schemes such as the Homes in Kalimpong were predicated on silences about an inappropriate past (in this case a racial past) so as to realize the potential for new beginnings in the colonies.

\section{I}

I feel parting with them keenly; but they have been mostly in the hands of natives, do not know a word [of] English and will I'm afraid be difficult charges. I beg for them a consideration of their wild upbringing, whilst confident they are in kind hands.

Egerton Peters to John Graham, 22 April 1906

A collection of letters written by Egerton Peters to John Graham, the founder of the Homes in Kalimpong, provides the foundation upon which this exploration of a parent-child relationship is built. Their correspondence began in 1905 and continued until 1936, and has been kept safely ever since in Lorna Peters' file by the Dr Graham's Homes' archive. ${ }^{6}$ Antoinette Burton has reminded us of the crucial role of archives (including domestic spaces and other less traditional sites) in shaping historical narratives. ${ }^{7}$ The Peters' family history has been profoundly impacted by two such repositories, both full of character and affording rich research experiences. The first of these was the Homes archive, a small cottage on the still-functioning school grounds. The second, also a small cottage, enters the frame in the second half of this essay. Peters' letters to the Homes enable the portrait of familial intimacy presented here because they deal with an intimate matter, a discrete matter about which he expressed feelings otherwise muted. Intimacy here is meant to invoke the physical proximities of everyday family life and the affections between a father and daughter, both of which were disrupted by Lorna's time at the Homes. Furthermore, intimacy also refers to the legacy of Peters' sexual relationship with Lorna's mother, a Nepali named Jhapri Ghurkali. The historiography of colonial intimacy has generally focused 
on these primary relationships rather than the families generated by them. This essay takes instead an intergenerational focus, looking to the shifts in family structure that occurred over a life-cycle and beyond. This legacy is particularly apparent in Peters' sense of loss over Jhapri's death in 1911. As I will suggest, the affection Peters felt for his native 'wife' is discoverable in his relationship with his daughter, and vice versa - the focus on the parent-child relationship suggesting a dynamic interplay between these two intimacies.

Assam was considered frontier territory when Egerton Peters, 20 years old, arrived in the district of Cachar in the mid-1890s. Ongoing conflict between indigenous peoples, various immigrant groups, and the British, had led to the establishment of an 'Inner Line' of British jurisdiction in the 1870s. This line drew a boundary around the valley, enclosing tea plantations in order to provide workers, both local and British, with added security. Access to the tea gardens and the roads that passed through them were strictly controlled. These were large estates, often employing several thousand workers - they were essentially small townships comprising significant ethnic diversity. Peters was first stationed in Backola as an assistant, the entry level position for Europeans that involved taking charge of one part of an estate. As an assistant, he was not allowed to bring a British wife with him to the plantation. Only a manager could do so, and it usually required an apprenticeship of ten years to gain this promotion. Given the isolation of plantation life and the absence of European women, cohabitation with local women was an accepted practice for British tea workers. However, this tolerance was mitigated by a high degree of disapproval in Britain. While in the earlier period of empire such liaisons were actually encouraged and could be made legitimate, from the late nineteenth century marriage to native women was no longer an option, and mixed race children could not be sent home to Britain for an education. ${ }^{8}$ Men such as Egerton Peters therefore cohabited with local women at considerable risk to their reputation. Although the remoteness of tea gardens often facilitated the discrete existence of these relationships, the arrival of offspring further complicated a situation that was becoming increasingly difficult to navigate.

Egerton Peters is likely to have shared his bungalow with Jhapri Ghurkali, and with their children. Lorna's first four years would have been spent entirely within the bounded and somewhat unusual space of a tea plantation, yet Peters' description of her 'wild upbringing' does suggest a relatively free existence. Her daily life would perhaps have been a mix of interaction with Jhapri's kin, and family routine aided by native staff in her father's bungalow. As Peters stated, she had been 'mostly in the hands of natives'. Though she did not speak 'a word [of] English', it is highly likely she communicated with her father in a local dialect. ${ }^{9}$ As Elizabeth Buettner has shown, parents of European children in India often retained this kind of relaxed approach to their children's upbringing, until such time as their education became a pressing issue. ${ }^{10}$ Given the importance of education and other cultural markers in defining racial status and hence dictating opportunity, reaching schooling age meant a child's identity must be taken in hand. Of course this was even more crucial when the mother was native. Because they could no longer send their mixed race children to Britain for schooling, those tea planters who wished to make educational provision for them faced a dilemma. Choosing instead one of the established schools in India that catered for both European and Eurasian children meant a possibly damaging public admission of their indiscretion. ${ }^{11}$ In addition, some of these schools would not accept a child who did not speak English, and the fees were out of reach for many planters. 


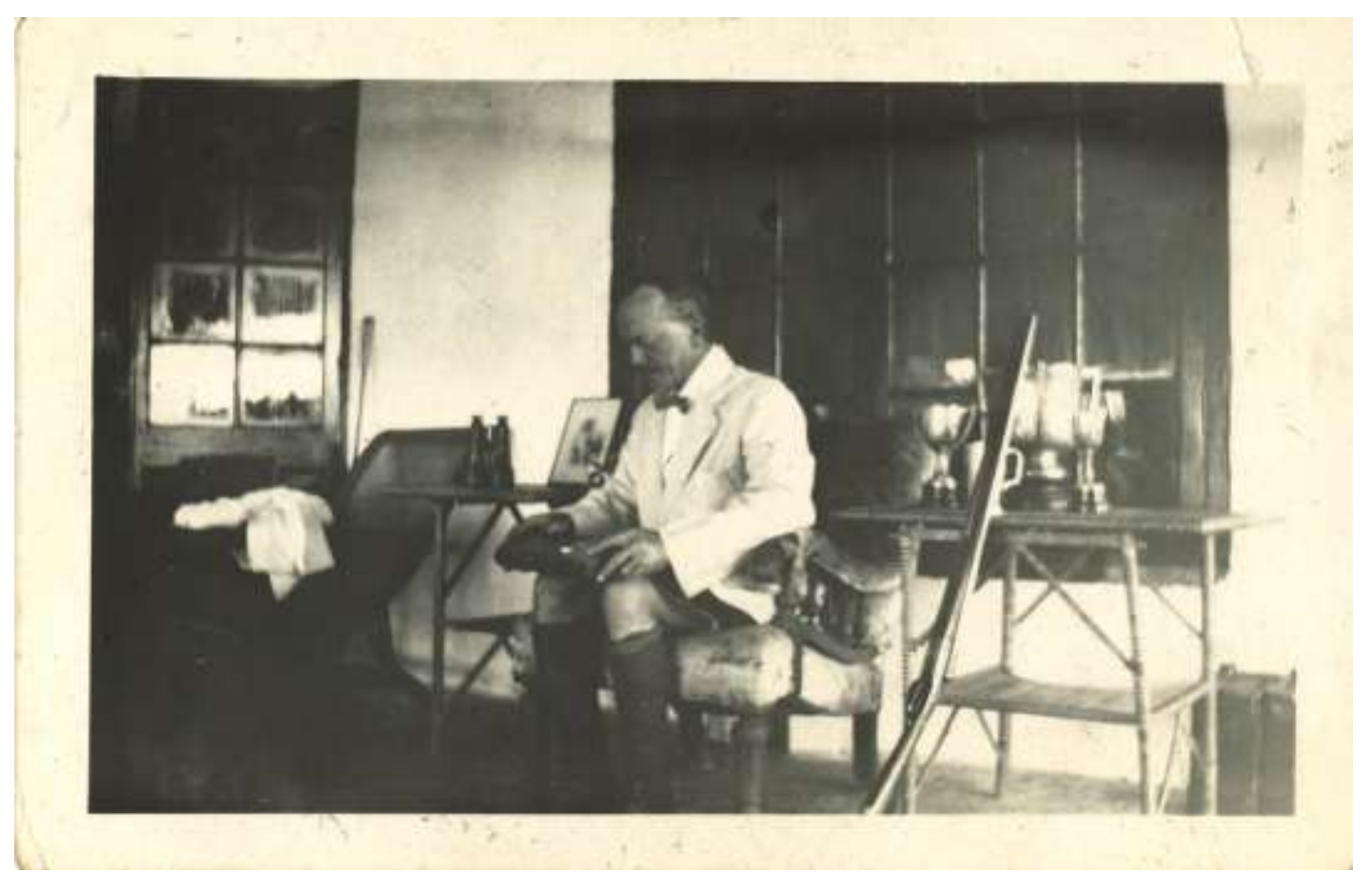

Figure 1: Egerton Peters in Assam, date unknown, private collection.

A consequence of these difficulties was that the Reverend Dr John Graham, a Scottish missionary in Kalimpong, found many 'light-skinned' children lingering on tea plantations beyond the age when they should have been in school. ${ }^{12}$ In his travels around the region in the 1890s, Graham came into 'sympathetic contact' with tea planters, many of whom would usher their mixed race children into the back of their bungalows upon his arrival. ${ }^{13}$ Others were more forthcoming about their plight, sharing with Graham their fears for the children's future. According to Graham, the bond between the parents was often 'a real and tender one'. ${ }^{14}$ But it was the children who were his chief concern, the ultimate impermanence of their parents' relationship casting uncertainty over their futures. The culmination of his concern and of several years campaigning both in India and in Britain, was the opening in 1900 of the St Andrew's Colonial Homes. A brochure printed at the outset made Graham's object clear - 'to attempt a solution of the problem by giving such a course of training as will fit the children for emigration to the Colonies'. ${ }^{15}$

The Homes in Kalimpong were set up along similar lines to institutions in various locations internationally whose programs were based on notions of reform through agricultural and domestic training. ${ }^{16}$ Graham secured a site of 40 hectares for the Homes (which would eventually expand to 242 hectares) and adopted a cottage system based on the Quarrier Homes in Scotland, which sought to provide an experience of family life by way of housemothers or 'aunties' in charge of each cottage. Staffing the school entirely with Europeans from Britain and the colonies, Graham sought to provide not only practical training but immersion in European cultural norms. The Homes were to be kept entirely free of injurious native influence', which meant the children would be responsible for the domestic duties in their cottage and around the school. ${ }^{17}$ Graham thought this self-sufficiency would stand the children in good stead for life in the colonies. It was this preparation of the children for life in colonial destinations that marked the Homes as distinct from other 
institutions that took in mixed race children; however it was a vision never to be realized for the majority. As Graham stated in the original brochure, those who were 'manifestly unfitted for Colonial life' were instead to be trained for openings in India. $^{18}$

This colonial solution to his children's future was one that appealed to Egerton Peters. He first contacted Graham in December 1905, with a brief and somewhat stilted enquiry about the possibility of sending his children to the Homes. In a letter marked 'Private and Confidential', Peters stated that he had two children, 'a little girl of three and a half and a boy of $1 \frac{1}{2}$ years of age', made an illegible comment about their mother, and simply asked, 'are they too young' and 'what are the conditions', adding that if large payments were required, this would 'make it impossible for me to send the children'. ${ }^{19}$ Two weeks later Peters wrote a letter more amiable in tone, referring to a favourable reply received from Graham. He offered an insurance policy to make long term provision for the children, whom he wished to 'stay permanently at the homes', until such time as they could be relocated to the colonies. ${ }^{20}$ While the Homes received funding from government agencies and private contributions, tea planters were expected to pay an amount up front as well as make monthly payments for their children. Arrangements were made over the next few months, during which time Peters moved to Lakhimpur and a position as manager. With the children departed on schedule, Peters sent a confirmation telegram from Silchar and a letter from home which mentioned, for the first time, his difficulty in seeing them go (cited above).

Peters' hope that the children would be in 'kind hands' suggests that the decision to send his children away was a difficult one. In making this decision he could look to his own childhood, which included separation from his parents and schooling in England while his father pursued a career in India. For Lorna and her mother no such rationale existed. It must have been a bewildering experience, a sudden and intense goodbye that a four year old can scarcely have understood. Lorna's early life running free on a tea plantation came to an abrupt end at precisely the age when she would have been laying down her earliest memories. It is highly likely that her first memories were indeed of this traumatic separation and the uncertain journey that followed.

\section{II}

I wish to do what I can for the children, but it is impossible for me to have any intimate relations with them. It would be far better for them to receive any presents I send anonymously and that they should regard their father as quite inaccessible. I sent them to the Homes, making a very considerable sacrifice as it seemed the best I could do for them. If I were to find it necessary for one to have direct relations with them I should [ ] feel compelled to leave India.

Egerton Peters to John Graham, 18 March 1917

With the children safely deposited at the Homes, Peters' communication with Graham apparently stopped for six years. This silence was sharply broken when Peters received a letter from the now ten-year-old Lorna in 1912. The letter was to mark the beginning of a dialogue that described an ongoing battle, essentially Peters' own internal battle, about how best to deal with the fact of his children's existence. His response to Lorna's letter, addressed to her housemother, maintained a deferential 
tone but strongly questioned the wisdom of putting his daughter in direct communication with him, and 'whether it was quite fair without consulting me'. ${ }^{21}$ Clearly rattled by the unannounced and unexpected breach of the distance between them, Peters declared that he 'should be delighted to hear from and write to the child if it did not appear to me to be against her best interests'. He considered that 'the atmosphere of a tea garden and close contact with natives would be decidedly objectionable for her', and worried that she would 'expect later to be sent to me for holidays'. This letter is one of many over the next eight years that convey Peters' difficulty in dealing with his absent children. The letters reveal the strange space Eurasians occupied in European ways of thinking; ambiguous and malleable beings even one's own daughter - whose (assumed) behaviours and traits betrayed a fear of blurred racial boundaries.

For those six silent years, Lorna had lived the life of an institutionalized child residing in a cottage with 40 other Eurasian girls and carrying out the daily chores she was assigned, attending classes and communicating in English. By 1912 there were several hundred children at the Homes, and an impressive array of cottages, school houses, workshops, and other facilities. In a dynamic environment that calls to mind Stoler's interest in the relation between 'prescription and practice', the primary interactions of children in this supposedly European space were, of course, with other Eurasian children. $^{22}$ The school's application form called for an assignation of the parents' nationality - Indian, Eurasian, or European - requiring further specificity for the Indian and European categories, but not so for the Eurasian. Mixedness was their essential and defining quality, and the specifics of their ancestry were deemed irrelevant. This simple categorization points to the Homes' view of the children, themselves all Eurasian, but also to the complexity in social distinctions between them. Some were from second or third generation Eurasian families in cities, others from the diverse ethnic communities living on tea plantations, still others turned up destitute on the Homes' doorstep. Graham sought to cut through these distinctions with his removal of native influence and substitution of European models, but the space between these two worlds was anything but simple. As Warwick Anderson has argued, 'the colonial reformatory thus produced - not eliminated - the in-between'.

The majority of the children of tea planters sent to the Homes would never see their parents again. Contact with native mothers was out of the question, and while Graham encouraged European fathers to play a continued role in their children's lives, it was a delicate situation and he was reluctant to press the tea-planters upon whom he relied heavily for financial support. As former student Eddie Lamb later recalled, most of the children at the Homes were from tea plantations, and in the vast majority of cases, our tea planter fathers simply abandoned us ... we received no letters or pocket money'. ${ }^{24}$ Eddie added that there were a few planters who sent drivers to collect their children home for the holidays, but this was a tiny minority. Lorna was never visited by her father at Kalimpong, and by all accounts had never heard of him prior to writing the letter in 1912. The Homes' part in her communication with her father suggests that there was no set policy for this kind of interaction. Peters concluded his letter in February 1912 by stating he had enclosed a note to Lorna, but left it at the school's discretion to show her or not. A dialogue between staff members begins with, 'What do you think? Wouldn't it be better to stop sending him letters?' Underneath a reply suggests 'get Birdie to write to Bunty.' A pen pal for Lorna (known as Birdie) was at this time the best solution staff could come up with; Bunty was a daughter of Graham, the founder of the school. In writing to her father, Lorna 
had unwittingly broken the boundary of the complex social space that had seen her cut-off from him for six years. This breach was facilitated by the staff of the Homes and it was they who navigated the fallout. Such was to be the nature of Lorna's relationship with her father for the next eight years.

This third-party management of her communication with her father rendered Lorna quite powerless in their relationship. However Peters did change his stance over the years, albeit in an unpredictable and confounding manner. In April 1912 he enquired as to the possibility of sending money for birthday presents, or of sending gifts himself if the school could advise him on the type of gift that would give 'the most pleasure'. ${ }^{25}$ In December that year he sent Christmas presents, to be given to 'the kiddies' with his 'best love'. ${ }^{26}$ From 1914 Peters began to request photographs of the children, requests that were apparently unanswered for a time. 'I have several times asked in the past nine months if I could have a photograph', he stated, as '[I] would be glad of an opportunity to form some idea of their ... appearance'. ${ }^{27}$ This highlights the total separation Peters had had from his children to this point. It was eight years since he had seen them and were he to pass them in the street he would not recognize them. Peters did receive photographs and continued to send presents, all the while expressing his uncertainty about the appropriateness of his responses. In 1915 he wrote that although it would give him 'great pleasure' to write to the 'poor child', it would be better to 'let her write and to thank one for presents ... so will you thank Birdie for me and give her my love'. ${ }^{28}$

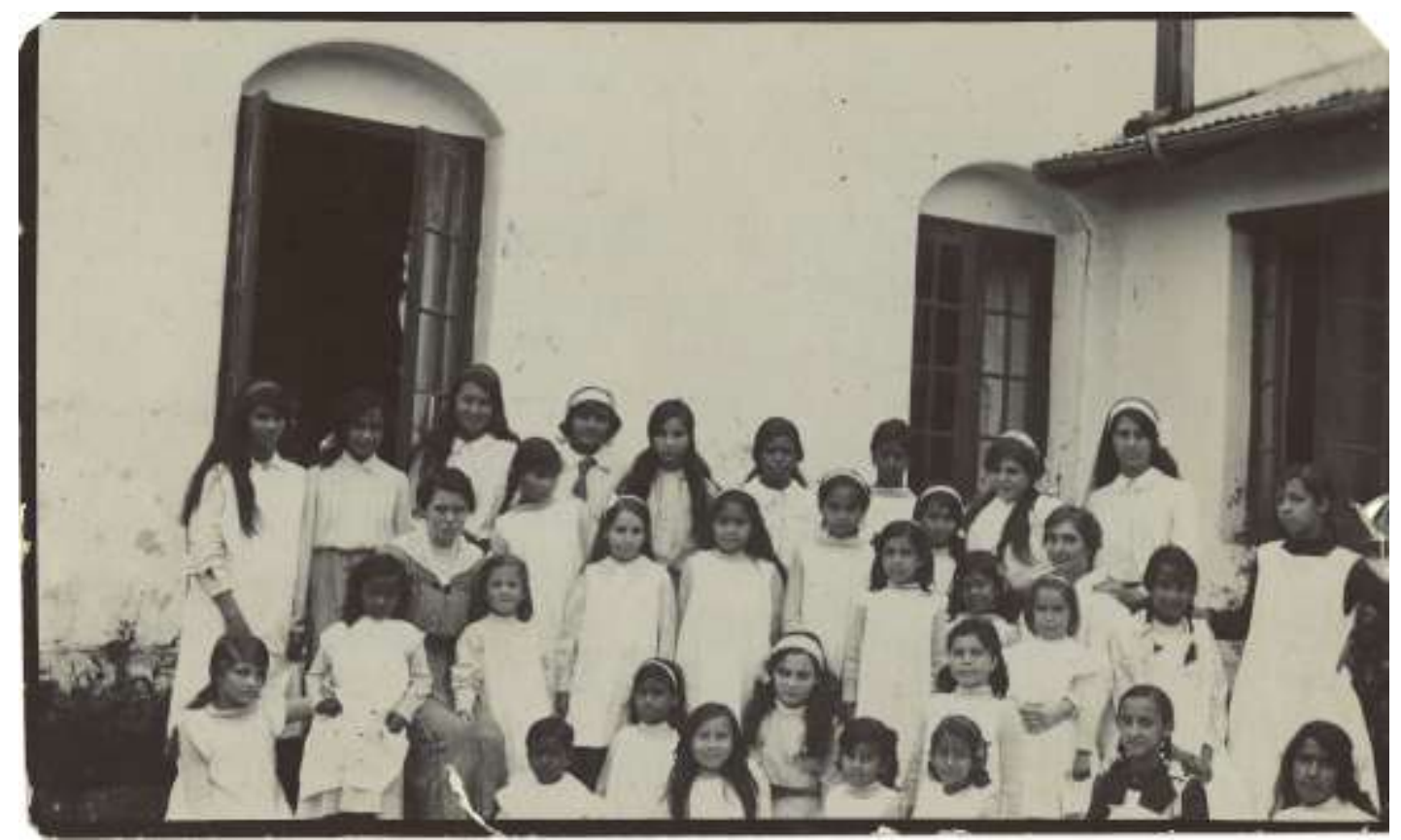

Figure 2: Woodburn Cottage, St Andrew's Colonial Homes, c.1916, private collection. Lorna Peters is standing on the far right.

Peters' desire for complete discretion regarding his children led to his reassessment of contact with them in 1917. In a strongly worded letter, he reported to the school two further breaches of his privacy. The first occurred 'about a year ago', when 'a lady whom I know well and whose [brother was a] very close friend of mine visited the homes and was shown the three children and informed that I was their father' (following Jhapri's death in 1911 Peters had sent his third child, Alice, to the 
Homes). ${ }^{29}$ Secondly, Peters had received a request from his son George for a photograph. The idea that the children should form some idea of his appearance led to the directive (cited above) regarding future communication that was, for once, unambiguous - he was to be anonymous, inaccessible, and 'any intimate relations' were impossible. As far as Peters' was concerned, letters and photographs exchanged directly between him and his children constituted an intimate relationship. This comment speaks to the crucial role of correspondence in maintaining empire families separated by large distances for long periods of time, a point Buettner has clearly argued. ${ }^{30}$ And while the Homes governed the space in which his children were living, it was Peters who controlled the ill-defined space between them in Kalimpong and himself, writing letters from a quiet bungalow in remote Cachar. He may have gained some sense of domestic fulfilment through indirect contact with his children, but his desire for discretion now overpowered any such sentiment. Only an acute concern about the children's lingering presence at the Homes (while others were sent to New Zealand) prompted him to re-establish correspondence.

In 1920 Peters wrote to Graham: 'After fourteen years, with Birdie 19 years old and George 17 years old I cannot discern that any arrangements whatever have been made for their future'. 'Brought up on the native side I could have arranged for their future suitably', he continued, 'as things are now I can do nothing beyond getting the facts before you and asking you to do your best for the children'. ${ }^{31}$ The colonial solution had been of the utmost importance in what Peters saw as a choice of identity for the children. However the Homes had experienced considerable difficulty in this regard due to the increasingly restrictive immigration policies of colonial governments. New Zealand, by far the most common destination for the Kalimpong emigrants, was no exception to this trend. By 1921, when Lorna and George immigrated, only 63 of these young adults had travelled to New Zealand; even fewer had gone to Australia, the United States and Britain. Motivated particularly by the plight he believed an educated Eurasian girl would face should she be 'turned out' to earn a living in India, Peters successfully negotiated Lorna's journey to what he perceived to be a land of fairer opportunity. His unstated motive was perhaps an interest in his own future, which likely included imaginings about meeting his daughter once again on more neutral ground.

\section{III}

We all thank you very much for your letter, which we received the first day on the Janus. We all also thank you for the lovely Bibles you gave us, we are sure to appreciate them very much as a last token of remembrance of the dear old Homes, which we all long to see once again.

Lorna Peters to John Graham, enroute to New Zealand, 1 January 1921

Lorna's first recorded words read like a breath of the fresh air that she sailed through on her journey to New Zealand. In contrast to her father's often anguished letters on her behalf, the two letters she wrote in 1921 conveyed an optimism that was likely quite genuine. After a period of stagnation at the school, where she had reached the limit of her training and lived in the same small cottage for fifteen years, the trip to New Zealand was surely an exciting one. Moreover Lorna's departure sparked a completely new phase of communication with her father. What had probably always seemed to her a simple desire, to establish a written correspondence with her father, 
was suddenly deemed entirely possible. Peters informed the school in December that he had written twice to her in Calcutta as she awaited departure for New Zealand. A few weeks later he requested her New Zealand address. After all of his misgivings and uncertainty during Lorna's time at the Homes, Peters' concerns dissolved instantly when she left. Social spaces are powerful things. In the course of 20 years, the relationship had moved not gradually, but in sudden moments of significant change, from a relatively unconstrained life on a remote tea plantation, to the strained terms of communication through an institution, and now to the imagined free space of a distant colony.

Apart from Lorna's two bright letters from the ship, we are still largely dependent on the words of others to keep her perspective in the foreground. We know from Peters' letters to the Homes that he established an immediate and ongoing correspondence with her following her move to New Zealand. 'Birdie's letters are invariably cheerful and very interesting', he wrote in 1921, 'she has a direct and quaint way of stating the facts as she sees them'. ${ }^{32}$ Through Peters' letters to the Homes we learn of Lorna's increasing familiarity with her father. She repeatedly made use of his influence, once for his help with problems with her employer, and on another occasion to obtain a photograph of her sister Alice who was still at the Homes. Lorna was able to relate to Peters on her own terms, and he took a keen interest in her situation. Lorna was living in Dunedin, in the South Island of New Zealand, which was the destination for the majority of the early emigrants from Kalimpong. This location was chosen largely due to the Homes' connections there, consisting of a small committee - one Rev Ponder and a Mrs Wilkinson - who were responsible for arranging farm and domestic positions for the Kalimpong students, and who kept a watchful eye on their progress.

But the suitability of Dunedin for the Kalimpong emigrants was not only a matter of connections. Dunedin in the 1920s was a place of some ethnic diversity, including a mixed race population from the local Kāi Tahu Māori. ${ }^{33}$ Graham's view that New Zealand was 'the best place in the world for the boys and girls of Kalimpong' was to a significant degree informed by his belief that the 'absence of colour prejudice' and high level of intermarriage there would allow his students to merge discretely into local communities, themselves perhaps mistaken for 'partMaori'. ${ }^{34}$ When Lorna arrived in Dunedin, 20 other Kalimpong students were already settled there, about whom the Homes' magazine published regular updates. In 1924 under the heading 'Dunedin Gossip', Kate Pattison reported on no less than 14 of those living in Dunedin, including several from Lorna's 'batch'. Dora Moller, Kate reported, was living 'two miles out of St Clair. All the same we usually see her on Thursdays', which suggests that there was a weekly get together. ${ }^{35}$ Another from Lorna's party, Mary Chaston, was living 'up at Dr Moody's' with Kate's sister. Mary's sister Gwen 'doesn't live very far from me. I expect her over for tea'. As for Lorna, Kate wrote that 'I saw Birdie Peters last Thursday, she was in town'.

Lorna herself had a letter published in the next edition of the magazine. 'You will see by the above address that I am away in the country for a holiday', Lorna wrote, 'what a happy family we are - Mrs MacDonald who was Auntie in my time at Woodburn, Mary Chaston, Dora Moller, George Peters and myself. It is beautiful here'. ${ }^{36}$ Meanwhile the correspondence with her father continued and in this same year, 1924, the first recorded mention of the possibility of Peters visiting her in New Zealand appeared in the archive. In a letter to Graham regarding Alice, who was reaching the age of leaving the Homes, Peters wrote that he hoped to take her to New 
Zealand himself. His travel plans featured again in May 1926, with another letter making arrangements for Alice; and in July Peters reported his imminent departure for New Zealand. 'Please give my love to Alice', he wrote, 'and tell her I'm looking forward to seeing her in NZ'. ${ }^{37}$ In the same month the Homes' magazine printed a message from Lorna that she looked forward 'eagerly' to the arrival of her sister. ${ }^{38}$ With herself and George already residing in Dunedin, her father on his way and Alice due to arrive later in the year, a family reunion of all but her mother was now a real possibility for Lorna.

The first archived letter from Peters in New Zealand was written to his aunt Caroline in London in November 1926. Caroline was the aunt with whom Peters stayed during his education in England, while his father shifted between postings in India, Afghanistan and Burma. This was a classic 'empire family' scenario according to Buettner's comprehensive work, until Peters strayed somewhat with his interracial relationship and family. His case thus presents an opportunity to assess the degree to which a mixed race family was integrated (or not) into the wider 'British' family network. Peters wrote regularly to his aunt, and she is the only known link he retained with his family in Britain. The only mention of his illegitimate family prior to his move to New Zealand was in 1923 when he wrote that he had received 'very good news from daughter and son in N.Z. The former writes a charming and intelligent letter. She has always been a good child'. ${ }^{39}$

Peters' 1926 letter to his aunt was written from a tiny settlement north of Dunedin where he had been staying for several weeks with Lorna. We are now looking for a small furnished house', he wrote, 'as my little daughter Alice should be here early in December and my son George will join us for a month or so about mid December, quite a family party'. ${ }^{40}$ Indeed; for Lorna it must have been an exciting and anxious time with her father living under the same roof as her, and by Peters' account she was very eager to please. 'We are very happy together', he wrote, 'she looks after me well, does the washing ... and even insists on cleaning the boots'. It is easy to imagine the potency such mundane duties would have assumed for Lorna given their prolonged separation. Peters concluded the letter with his vague plans for the future. 'I suppose I shall have to go back to tea', he mused, 'if I go back Birdie will go with me ... I shall at least go back very fit and have Birdie to look after me'. His words tell us that Lorna again faced an uncertain future, and also paint a slightly awkward picture of their relationship. It was unsurprising to learn that future generations of the Peters family assumed he was writing about his wife in these letters.

As it happened, Peters' visit to New Zealand was to be a permanent relocation. Two months after the above letter was written he purchased a property at Pine Hill, on the outskirts of Dunedin, and with his daughters set about establishing a small farm. In mid-1927 he reported to his aunt Caroline that 'Birdie braves the weather like a good un, helps me, I can't stop her doing it and looks well after her poultry with which she is very successful'. ${ }^{41}$ From the outset this was and would continue to be an isolated and tough existence, a tiny cottage the only shelter from the bracing winds and long days working to tame the 6 hectare property. Peters wrote to the Homes later in the year in response to a request for assistance placing Kalimpong boys in farm work. 'We would of course be willing to do anything possible', he wrote, 'but we go nowhere and see no one and only know one of our neighbours fairly well'. 'We do everything ourselves and a very hard life it is too', he continued, 'but I hope that in the course of two or three years we may be better off and able to look about a bit'. ${ }^{42}$ 
IV

Birdie (herein referred to as Lorna) is busy with domestic duties and asks me to write a few lines. In [particular] to thank you very much for all the magazines and to say our present circumstances make any contributions impossible. We are running this in partnership and as you know times are bad ... it has been hard going.

Egerton Peters to John Graham, 6 June 1934

Peters' hopes that the work would ease were not to be realized in any short time. Alice took up a domestic position with a family north of Dunedin in 1928, and George continued his itinerant work around the Dunedin area. And so it was Lorna and her father who worked together to establish their poultry farm, building sheds as required, hampered as ever by the 'terrible climate'. Between 1928 and 1934 there is only one surviving letter from Pine Hill, this from Lorna to her great-aunt Caroline. 'Father has not been well lately', she wrote, and 'Father and I enjoyed your book... also the paper cuttings you so kindly send us'. ${ }^{43}$ In her tireless work to establish the Pine Hill property as a working farm and home for them both, Lorna had not only created a strong bond with her father but also established a place for herself in the broader family network. Peters' correspondence to the Homes and to his aunt recommenced in 1934, and there is a marked sense in his words of Lorna having assumed a large portion of responsibility for the running of the household. He spoke of the farm as a partnership with Lorna, and his tone moved to one of open admiration for her capacity to work long days in good humour. Peters himself was growing old and, as cited above, he wrote to the Homes at Lorna's behest in an effort to alleviate her burden. He began to refer to his daughter as Lorna and this would persist. 'I invariably call her Lorna', he wrote to the Homes in 1935, 'and refer to her as Lorna amongst our neighbours'. ${ }^{44}$

This change of name, perhaps in Peters' eyes signalling her graduation from child to adult, was soon to be paired with a new surname. In 1935 Peters announced his daughter's marriage to William McCabe, of whom he approved. Birdie Peters became Lorna McCabe and in many ways she never looked back. The aging Peters, quite dependant on his eldest child to establish an income from the family property, now also owed to her a continuation of the family line. Lorna's first child, William Egerton McCabe, was born in 1936. Peters boasted of his grandchild to his aunt as any proud grandfather would, and Caroline sent presents for the young Billy. We could observe that in this final phase of the father-daughter relationship a certain naturalization occurred. Peters' increasing reliance on Lorna can be seen as a reversal of parent-child roles that is common towards the end of the lifecycle. What is noteworthy here is that such normalities were possible given the somewhat disturbed history of this unlikely pair. Both had something to gain from the arrangement at Pine Hill - for Lorna the affection of her father and for Peters perhaps his first real opportunity to experience a settled home and family life.

The impression that Lorna was assuming a dominant role on the farm was reinforced by the perspective of an outsider in July 1937. Dr John Graham, from the Homes in Kalimpong, visited the Pine Hill farm as part of a tour around the colonies to visit his ex-students. 'I shall never forget the experience of going over it and of seeing Birdie in the midst of her work', wrote Graham in his private diary, 'she is the undoubted leader'. ${ }^{45}$ Lorna took him on a tour of the poultry farm, the 300 chicks that were her responsibility and the older fowls that 'she leaves to her father and husband'. 
Regarding Peters, Graham found it 'remarkable to see him who used to be a great polo player in Cachar in the midst of it all'. While it seems an unlikely scenario for a tea-planter to follow his mixed race children to the colonies, early research into the wider group of Kalimpong emigrants has revealed at least three other cases where teaplanters visited or lived with their children in New Zealand. One of these families, a tea-planter and his two daughters, was also visited by Graham in 1937. In contrast to the Peters/McCabe family of Pine Hill, the Dinnings of Wellington participated fully in the various public activities held in honour of Graham's visit. Mr Dinning met Graham at the train station and drove him to various appointments around the city. Conversely, Graham was driven by a Kalimpong old boy to the Pine Hill property, and there is no record of the Peters' attending any of the social functions held in Dunedin. Perhaps Peters' choice to live out his days with Lorna, while based partly on notions of New Zealand's freedom from the complexities of class and caste, also depended on him leading an enclosed existence in which the boundaries of this social landscape were not fully tested.

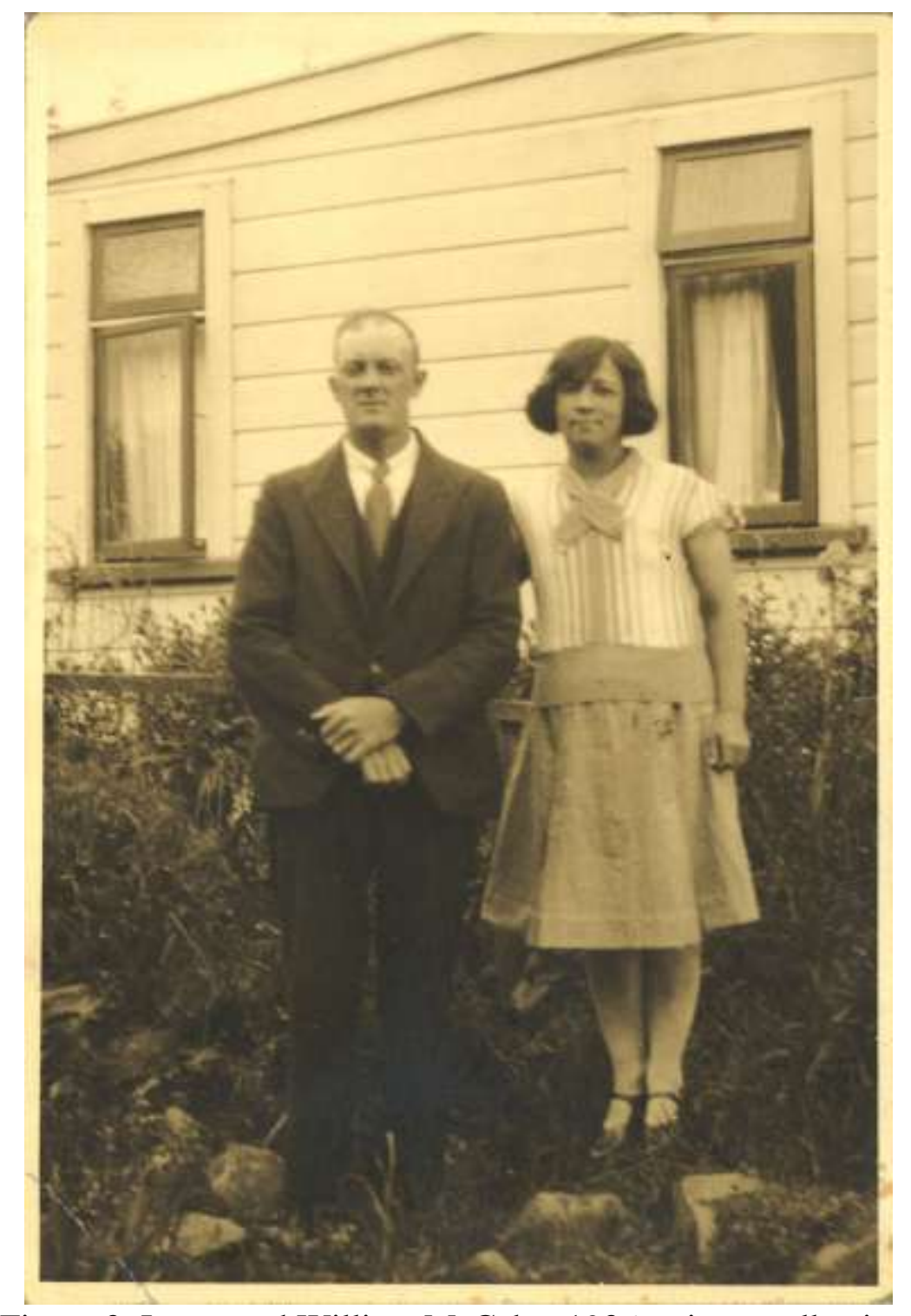

Figure 3: Lorna and William McCabe, 1936, private collection. 
Peters would live for another ten years, time enough to see the birth of a second grandchild. It is at this point that the archive for this story takes on a new dimension. That second child, Donald, was my father. One of his earliest memories is of Peters' death, a sudden and traumatic event for the family, and for the five-year-old Donny. It is an interesting historical juncture, a meeting point of sorts, where through my father's memories of Lorna I am able to reach back towards the point where her father's words, the written words that gave momentum to this story, cease. Somewhere in this meeting of archival record and voiced memories resides an understanding of this aspect of Lorna's life, this racial past in which her early life became a time that she would never speak about. My father knew nothing of his mother's upbringing before my visit to the Homes in 2007 after a chance discovery of a single photograph captioned 'Kalimpong school'. He does remember Lorna speaking often about Peters, associative memories prompted by pride in the legacy of his handiwork around the farm; while my mother remembers Lorna telling her that Peters had said that the day Jhapri passed away was 'the saddest day of his life'. This one delicate memory of the children's mother is paired well with Peters' comment in 1912 - the year after Jhapri died - that he was 'unlikely to form other ties'. ${ }^{46}$ At just 36 years old, by then a manager of a tea plantation, and with the children at the Homes, it was entirely possible for Peters to have taken a British wife. He chose instead to invest in his existing ties, those tenuous ties with his children.

As for my own memories of Lorna, I was five years old when she died. I remember her as an old woman with a shrill voice who waddled about with great difficulty. My understanding of her relationship with Egerton Peters is enriched by my ongoing association with the small cottage at Pine Hill - the second archive of this story - where my parents now live and where I spent every Sunday afternoon throughout my childhood visiting my uncle and grandfather. The cramped, dark space of the cottage was one that meant, especially as children, we always felt slightly in the way. This was not a residence that allowed any privacy, any demarcation of space, any physical aloofness from each other. As a child I was distinctly aware of the kindly portrait of Peters that hung on the wall, the large antlers that loomed over us, and the Volunteer Force medals and polo trophies from Assam on the mantelpiece. As a child these objects took on the 'strangely familiar', somewhat haunted quality that both Anne Stoler and Laura Bear have suggested is a legacy of imperial intimacies that crossed racial boundaries. ${ }^{47}$ Even then, these objects spoke of the importance of Egerton Peters in Lorna's life. The prolonged separation from her father during childhood would have intensified greatly the everyday experience of living with him in New Zealand. The pulse of this story pounds with the thought of him in the next room; him eating food she had prepared; him praising her. With time, and as this intensity lessened, Lorna came to live on her own terms, her ties to Kalimpong thinning to the finest of threads - threads that would be picked up many years later, quite by chance, by an inquisitive granddaughter.

Archives have enabled a transformation in the understanding of my family history. However this enabling is countered by the tendency for archives to dictate, and here the temptation is to write Lorna only in her father's words. My progress towards a greater certainty in my writing of her owes much to the realization that it is her heart I hear booming in the moments described above. Lorna's experiences have reached forward and profoundly affected her family in ways that are difficult to articulate. That legacy speaks not only to the pattern of dislocation and isolation that pervaded the Peters' family history. For Lorna, the unexpected element of key events, 
both joyful and traumatic, contributed to their heightened emotive impact. Peters' mobility as a man of empire enabled him to navigate a journey towards a home with his daughter, and yet he remained constrained by the rules of his class. Lorna, on the other hand, traversed these large distances entirely at the behest of others, the benefit of which was a difference in perception that amounted to a relative freedom. When Lorna stepped outside her door the atmosphere was surely not as charged with judgement as it was for her father. These layered experiences are not easily captured nor explained, yet they go some way towards filling the vague space between official imperatives and personal responses. Social landscapes, about which it is tempting to generalize, are only a reality in so much as they are perceived, believed and acted upon.

The specific sites of this story - a remote tea plantation, an institution in a tiny hill station, a cottage dwarfed by wild acres and pine trees - bear a remarkable resemblance to each other. In terms of physical presence they are all isolated in setting, and all contain small dwellings dominated by large expanses of land. Each bears unique social boundaries, and each invites an exploration of the lived experiences within. Two of these sites house the bulk of archival material used in this essay, and their continued existence is embedded in the intimate rendering of the Peters' story. The archive of this father-daughter pair provides a rare and privileged insight into the history of a transnational family, and provides clues to the wider story of Eurasian emigration yet to be fully explored.

In broader terms this essay adds weight to Stoler's argument that a focus on intimacy dissolves certain intellectual divisions. ${ }^{48}$ This essay began with a simple distinction between social pressures in British India and New Zealand. That distinction was complicated firstly by the specific nature of the regions, the landscapes and the dwellings within those larger national structures; and secondly by the social and familial circumstance that is of interest here. The focus on intimacy has enabled all of this complexity to be explored, but in the process has illuminated a very human story - a story of dislocation and reunion, silence and reconnection, understanding and regeneration.

\footnotetext{
${ }^{1}$ E.G. Peters to J.A. Graham, 24 April 1906, Dr Graham's Homes Archive (DGHA), Kalimpong, India.

2 This use of the term 'Eurasian' was officially replaced by 'Anglo-Indian' in 1912. For consistency Eurasian is used throughout this essay as per the primary sources used here.

${ }^{3}$ Ann Laura Stoler, 'Intimidations of Empire: Predicaments of the Tactile and Unseen', in Ann Laura Stoler, ed., Haunted by Empire: Geographies of Intimacy in North American History, Durham, 2006, p.2.

${ }^{4}$ Tony Ballantyne, 'The Changing Shape of the Modern British Empire and its Historiography', The Historical Journal, 53, 2 (2010), p.435.

5 Tanya Evans, 'Secrets and Lies: The Radical Potential of Family History', History Workshop Journal, 71, 1 (2011), pp. 51-54.

${ }^{6}$ The St Andrew's Colonial Homes were renamed 'Dr Graham's Homes' after the founder of the school, the Rev. Dr John Anderson Graham, following his death in 1942.
} 
${ }^{7}$ Antoinette Burton, ed., Archive Stories: Facts, Fiction and the Writing of History, Durham, 2005, p.9.

${ }^{8}$ Ronald Hyam, Empire and Sexuality: The British Experience, Manchester, 1990.

${ }^{9}$ Roy Moxan cites an early superintendent describing assistants who did not speak the local language as 'worse than useless', in Tea: Addiction, Exploitation and Empire, New York, 2003, p.121.

${ }^{10}$ Elizabeth Buettner, Empire Families. Britons and Late Imperial India, Oxford, 2004, pp.29-62.

${ }^{11}$ James Minto, Graham of Kalimpong, Edinburgh, 1974, p.54.

12 ibid.

13 John Graham, Typed Notes, National Library of Scotland (NLS).

14 ibid.

${ }^{15}$ John Graham, St Andrew's Colonial Homes brochure, NLS.

${ }^{16}$ Ann Laura Stoler, 'Tense and Tender Ties: The Politics of Comparison in North American History and (Post) Colonial Studies', in Stoler, ed., Haunted by Empire, pp.43-48.

${ }^{17}$ Graham, Typed Notes, NLS.

${ }^{18}$ Graham, St Andrew's Colonial Homes brochure, NLS.

${ }^{19}$ E.G. Peters to J.A. Graham, 8 December 1905, DGHA.

${ }^{20}$ E.G. Peters to J.A. Graham, 27 December 1905, DGHA.

${ }^{21}$ E.G. Peters to Miss McCrie, 23 February [1912], DGHA.

${ }^{22}$ Stoler, 'Tense and Tender Ties', p.25.

${ }^{23}$ Warwick Anderson, 'States of Hygiene: Race "Improvement" and Biomedical Citizenship in Australia and the Colonial Philippines', in Stoler, ed., Haunted by Empire, p.96.

${ }^{24}$ Homes Centenary Publication, Daddy Graham's Homes, Kathmandu, 2000, pp.140-1.

${ }^{25}$ E.G. Peters to J.A. Graham, 28 April 1912, DGHA.

${ }^{26}$ E.G. Peters to J.A. Graham, 23 December 1912, DGHA.

${ }^{27}$ E.G. Peters to J.A. Graham, 21 October 1914, DGHA.

${ }^{28}$ E.G. Peters to J.A. Graham, 18 January 1915, DGHA.

${ }^{29}$ E.G. Peters to J.A. Graham, 18 March 1917, DGHA; E.G. Peters to J.A. Graham, 28 April 1912, DGHA.

${ }^{30}$ Buettner, pp.130-39.

${ }^{31}$ E.G. Peters to J.A. Graham, 27 July 1920, DGHA.

${ }^{32}$ E.G. Peters to J.A. Graham, 21 November 1921, DGHA.

33 According to the 1921 Census 'race aliens' (including 'half-caste' Māori, Chinese, Syrians and Indians) in Dunedin numbered 59 to every 10,000 Europeans. The Results of a Census of the Dominion of New Zealand, 17 April 1921 - Part IV, Wellington, 1923, p.5.

${ }^{34}$ Graham, Typed Notes, NLS.

35 'Dunedin Gossip', St Andrew's Colonial Homes Magazine, vol. XXIV, no. 1/2, 1924, p.14.

36 'For the Old Boys and Girls', St Andrew's Colonial Homes Magazine, vol. XXIV, no. 3/4, 1924, p.36. Woodburn was the name of Lorna's cottage at the Homes.

${ }^{37}$ E.G. Peters to J.A. Graham, 13 July 1926, DGHA.

38 'News of NZ', St Andrew's Colonial Homes Magazine, vol. XXVI, no.3/4, 1926, p.34. 
${ }^{39}$ E.G. Peters to C.S. Peters, 15 October 1923, Peters' family collection (PFC), transcribed by Alistair Gordon, 2005.

${ }^{40}$ E.G. Peters to C.S. Peters, 16 November 1926, PFC.

${ }^{41}$ E.G. Peters to C.S. Peters, 29 July 1927, PFC.

${ }^{42}$ E.G. Peters to J.A. Graham, 22 November 1927, DGHA.

${ }^{43}$ L.B. Peters to C.S. Peters, 30 April 1930, PFC.

${ }^{44}$ E.G. Peters to J.A. Graham, [?] July 1935, DGHA.

${ }^{45}$ Dr Graham's Diary, 1937, NLS.

${ }^{46}$ E.G. Peters to J.A. Graham, 28 April 1912.

${ }^{47}$ Stoler, 'Intimidations of Empire', p.14; Laura Bear, Lines of the Nation: Indian Railway Workers, Bureaucracy and the Intimate Historical Self, New York, 2007, pp.264-7.

${ }^{48}$ Stoler, 'Tense and Tender Ties', p.58. 